\title{
Public Space as Interior and Interior as Public Space
}

\author{
Jaroslav Dad'a* \\ Department of Architecture, Czech Technical University in Prague, Czechia
}

Submission: March 30,2021; Published: April 15, 2021

*Corresponding author: Jaroslav Dad'a, Department of Architecture, Faculty of Civil Engineering, Czech Technical University in Prague, Thákurova 7, 16629 Prague 6, Czechia

Keywords: Optimal design; Built environment; Public space; Building interiors; Aesthetic aspects; Bloodstream; Boulevard; Passage; Piazzettas; Courtyards; Bridge tower; Umbilical cord; Easy orientation; Building by analogy

\section{Principles and Contexts in the Formation of Public}

\section{Spaces and Interiors}

The saying that there is only one architecture holds true. The breadth of architectural tasks ranges from chair design to urban plans, but in reality only the scale changes, the principles and creative tools remain the same. The compositional principles are used again and it is up to the architects to use them for the solved task and how to evaluate their effect for optimal design. We can document this in the context of urban space and building interiors. I would liken the public space perceived by the architect's point of view to the interior of the building by analogy. The public space is the interior of the built environment. The mutual analogy between the parts of the city and the interior of the buildings that make it up is supported by similar means of expression in their creation. The same rules apply to the design of the interior and public space as for any architecture. The scope and size of the solution are different, but the principles for the solution remain the same.

Designing and shaping the interior and public space is a complex matter, at the end of which is a functional architecture for a people. Operational and aesthetic aspects must go hand in hand. Public space, like a room or communication in a house, leads somewhere, has a function and something takes place in it. Just as individual rooms have a purpose, so do the exteriors of our cities. Somewhere it is necessary to speed up to just pass, somewhere there is space for stopping, gathering, resting, etc. As in the interiors of buildings, the architect must support these required functions with means of expression, create the necessary atmosphere, easy orientation, facilitate maintenance, promote safety, etc.
The street space, like the corridor, is linear and has the task of facilitating the flow of people in both directions, signaling entrances to buildings, resp. rooms set up along it. Streets and corridors function as veins and arteries in the body of buildings and cities. They create a bloodstream that supplies life to the city and its houses Figure 1.

By widening the street, we get a boulevard, which can be compared to a passage. The boulevard is a street of greater importance and greater width. Similarly, the passage is the superior line space in the interior. Streets and boulevards then converge on the square, just as corridors and passages lead to halls, which are centers for gatherings, and therefore the most important places.

Smaller spaces are rooms or small squares in the city, piazzettas. The one-sided oriented longitudinal spaces of the colonnade can then be boldly compared to galleries. And finally, the atriums or patios are courtyards, ie spaces surrounded on all sides. An example of a public space that evokes an association with the interior is Křižovnické náměstí in Prague. The space, founded in the Middle Ages, is one of the most beautiful small squares in Prague with its picturesqueness. From the north, the square is bounded by the Church of St. Francis and the Monastery of the Crusaders, from the east by St. Salvator, from the south by a number of burgher houses and from the west by the Bridge Tower.

The charm of the whole space lies mainly in contrast to its closed nature with an open view of Prague Castle. As we walk through the square from east to west, we experience the feeling 


\section{Civil Engineering Research Journal}

of a man in a beautifully furnished room facing the window, from which a fascinating view of the exterior opens up. If we observe Prague Castle from Křižovnické náměstí, we experience a telescopic effect, when the castle appears closer to us than it actually is. Prague Castle as a large giant and a small space intimately tuned against it, tied with the umbilical cord of Charles Bridge. Square as a room with a view and a room with a view as a square. The design of public spaces is in many ways very close to the spatial solution of the interiors. Spatial principles work across all architectural disciplines Figure 2.
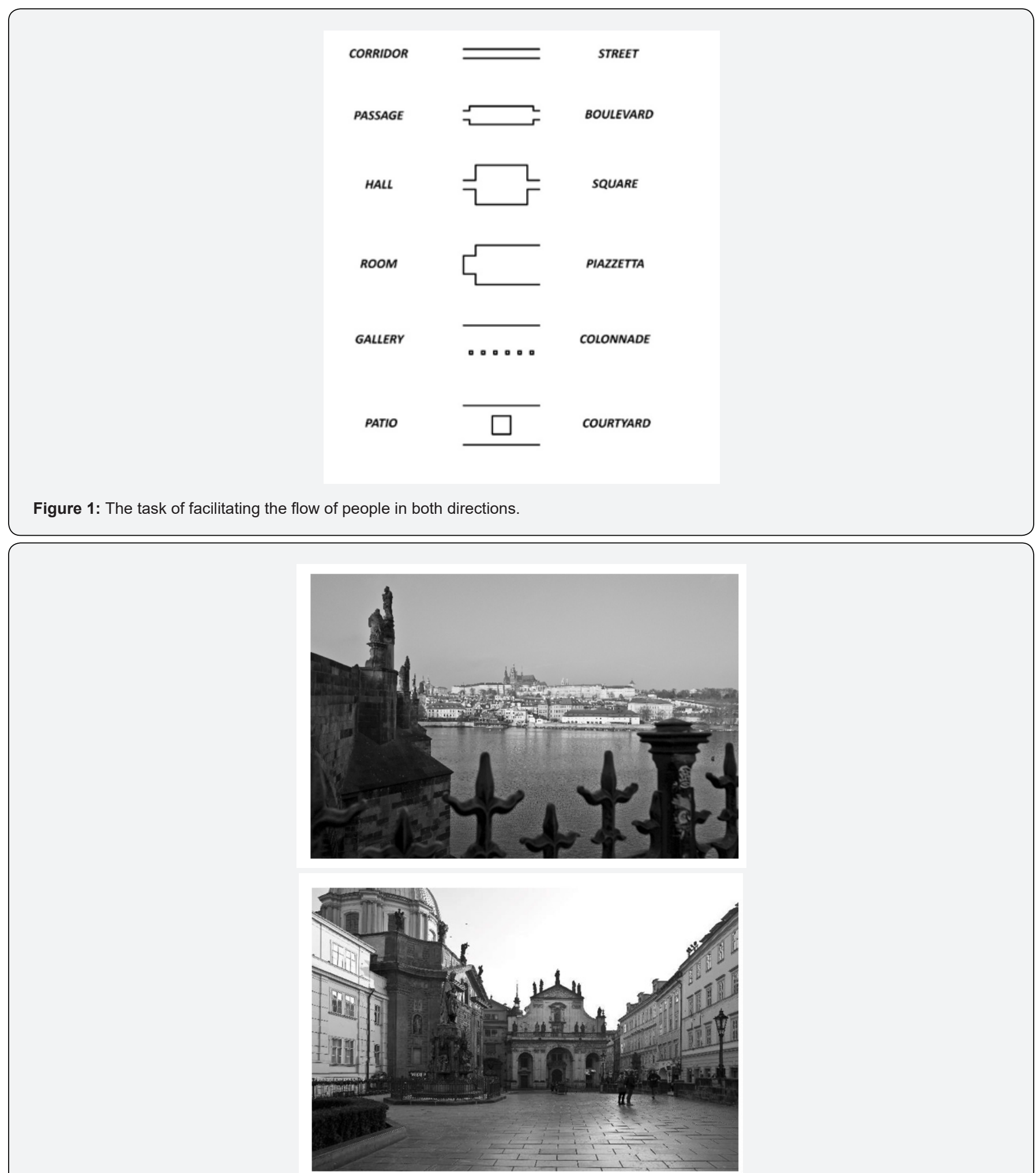

Figure 2: The design of public spaces is in many ways very close to the spatial solution of the interiors. 
This work is licensed under Creative Commons Attribution 4.0 License DOI: 10.19080/CERJ.2021.11.555816

\section{Your next submission with Juniper Publishers will reach you the below assets}

- Quality Editorial service

- Swift Peer Review

- Reprints availability

- E-prints Service

- Manuscript Podcast for convenient understanding

- Global attainment for your research

- Manuscript accessibility in different formats

( Pdf, E-pub, Full Text, Audio)

- Unceasing customer service

Track the below URL for one-step submission https://juniperpublishers.com/online-submission.php 